\title{
The Effect of Middle Manager Engagement on SCM Performance through ERP System and SCM Practices
}

\author{
Zeplin Jiwa Husada Tarigan ${ }^{1+}$, Hotlan Siagian ${ }^{2,}$ and Widjojo Suprapto ${ }^{3}$ \\ ${ }_{1,2,3}$ Petra Christian University, Surabaya, East Java, Indonesia
}

\begin{abstract}
Partnerships will give a new demand for manufacturing companies to build a data integration system that can synchronize quickly. This condition will provide the company with best practices in carrying out the operations in an integrated manner with suppliers and distributors and customers. Supply chain integration ( $\mathrm{SCI}$ ) as a form of supply chain best practice is obtained by the implementation of technology enterprise resource planning (ERP) so that the data are obtained at the right time, complete and accurate. The supply chain best practices and the ERP can increase the supply chain management performance flow. The implementation of the SCM and ERP system is the responsibility of the middle manager. The distribution of questionnaires is carried out to 60 industries and 80 questionnaires, with a response rate of $74 \%$, which can be further processed with PLS analysis. The results of the data processing show that the middle manager engagement is able to bring a positive impact on the implementation of ERP systems and SCM practices. Then, the middle manager engagement is able to bring a positive impact to the SCM performance by reducing the company's operational costs. The ERP system implementation in the company can have an impact on SCM practice and performance. The SCM practices that have been continuously impacting on SCM performance.
\end{abstract}

Keywords: Middle manager engagement, SCM performance, ERP system, and SCM Practice

\section{Introduction}

The escalating intensity of competition in the business world encourages many companies to carefully shape their corporate strategy. The intense competition among various companies also affects the supply chain management of those companies. Besides, the globalized supply chain implementation plays a role in shortening the product life cycle. The supply chain is interdependent and interrelated networks which work together in controlling, organizing, and increasing the material and information flow from the suppliers to the consumers. Many companies have to design each of the supply chain processes from the material procurement to the final product distribution, through various internal coordinating and collaborating processes among different departments, in order to increase the profits and to maximize the business strategy. The supply chain is acting as the connectors to coordinate the suppliers, the companies, and the customers through the collaborative process of the information and knowledge sharing. Supply chain integration is building the company systems to become more efficient and effective [1]. In Indonesia, many companies have implemented the supply chain management (SCM) system gradually to sustain their production operations. The implementation of supply chain management must be accompanied by the implementation of information technology so that the system can be easily monitored and controlled by top management. In running the supply chain management, however, the middle level of managers play an essential role in maintaining the company's infrastructures and facilities, in controlling and organizing the company's logistics and delivery, in analyzing the company's data and information systems, and in procuring the company's raw material and pricing strategy. Gandhi et al., [2] state that the supply chain practices bring a positive impact to the company's overall performance and financial performance in retail companies in India.

\footnotetext{
+ Corresponding author. Tel.: +61312983145

E-mail address: zeplin@petra.ac.id
} 
Sundram et al., [3] mention that the six dimensions of SCM are the supplier strategic partnership, information sharing, agreed on vision and goals, postponement, risk and reward sharing, and information sharing, and the last dimension that does not affect the performance is the customer relationship. The supply chain practices which are consisting of three levels: managerial process, information technology, and information system, and operational process [4]. The use of information technologies and information systems in those manufacturing companies are often considered as implementing the enterprise resource planning system. The implementation of ERP is expected to integrate various data from related departments so that the internal corporate changes can be synchronized with the external suppliers and customers.

\section{Background Theory}

\subsection{Enterprise resources planning}

The system changes that happen in the company's operations will affect the changes in the company's ERP system, and in that way, the ERP system can give real-time situation updates. The integration among various departments is a requirement to maintain and develop the ERP system in a company. The successfully integrated ERP systems among departments can help the managers analyze the operational processes of the organization comprehensively. The ERP system implemented in the company can give a practical solution for the organization to improve its performance. The ERP system integrates all departments with one single data entry within in manufacturing company [5]. The ERP system can provide more accurate and better-quality data so that the organization can run by the standardized operating procedures. The ERP system can run smoothly in an organization if the employees conduct the data entry properly, which is as stated by the real operational condition. The indicators to measure the ERP system in this research are: the integration department functions, the data integration is accurate, the data integrity is complete, ERP data reliability, and the objective of the data integration is comprehensible.

\subsection{Middle manager engagement}

Running the ERP system in the company is usually conducted by the key users, who are the appointed representative from each department in the organization, and these key users are generally the managers of the departments, who are categorized as the middle managers. The middle managers have essential roles in the organization as they are responsible for developing the systems in their departments and to make decisions on the operation of the company. These internal and external collaborations will bring impacts to the supply chain practices, through the middle managers' engagement to the ERP system, which finally increases the performance of the supply chain management [6]. Engagement means an active involvement of employees in developing and delivering the success of the organization. Employee empowerment can be interpreted as involving employees to improve organizational performance [7]. Employee empowerment is not only giving input to the organization but also paying attention and following up the input to be implemented. Employee involvement also increases the sense of belonging and responsibility for decisions by involving the employees to achieve the company goals. Middle managers must be able to build an effective communication system and create open access to the ERP system for all employees. The communication system will provide a sense of engagement for every employee, and middle manager engagement can manage ERP to run well for the needs of the organization.

The work environment and work culture created by the organization can have an impact on employee involvement to learn and to engage directly in the company. As the item of employee engagement is to use employee communication, reward and recognition, and employee development [8]. For their research, Ajayi et al., [9] use measurement items such as having a personal pride while working in the company, having a personal pride while accomplishing the task, having the opportunity to do the job well, getting the feedback on work results, having superior work supports, understanding the company's goals, and having major contributions to the company. For this research, the indicators to measure the middle manager engagement are their contribution to the department goals [7,9], actively engaged in communication with other departments [8], the opportunity to develop the job [7,9], and the opportunity to join training [8]. 


\subsection{Supply chain practice}

The implemented supply chain practice to reach the optimal SC performance needs some integration across internal functions within the company and external parties as suppliers and customers [10]. SC practice is with indicators such as supplier collaboration, flexibility partners, connected and usage of internet, customer focus with satisfaction, lean production system, with internal integration, and quality management system [11]. The SCM practice in retail companies in India as customer relationship management, supplier relationship management, goal congruence, and information sharing [2]. Sundram et al., [3] in their research about the SC practice on electronic manufacturing indicators, such as supplier strategic partnership, information sharing, postponement, risk and reward sharing, and customer relationship. Therefore, in this research, the indicators for this supply chain practice variable are supplier collaboration, information sharing, lean production system, with internal integration, and total quality management system.

\subsection{Supply chain performance}

Every company has evaluation mechanisms, which measure and evaluate its effectiveness and efficiency. In SCM, a performance measurement system is needed to monitor and control, to communicate the organizational goals to other functions within the supply chain, to know the relative positioning with the competitors and to the target of the organization, to set revised direction in creating the competitive advantage. The SC performance, which is measured using qualitative methods, includes customer satisfaction, integrated information, effective risk management, and supplier performance [3]. Meanwhile, the SC performance, which is measured with the quantitative method, includes the cost of production, sales, profit, logistics, return on investment, fill rate, accurate delivery, response time, and lead time. Company's performance that is measured from SCM includes market performance, financial performance, and customer satisfaction [10]. The research conducted by Al-Shboul et al., [11] reveals that measuring SC performance includes the SC flexibility, SC integration, customer responsiveness, and supplier performance. The indicators used to measure the SC performance in the manufacturing companies for this research are integrated information, perfect order fulfillment, flexibility, responsiveness, and cost reduction.

\section{The Conceptual Research Framework}

The SC performance can be conducted through the implementation of ERP so that there is real-time data connectivity among internal departments and external parties. The practice of SCM becomes the main operational functions and activities in the company to surrender an effective and efficient SCM, which is the primary goal of implementing the SCM. The data integration will be considered as an ERP system if it can provide accurate, complete, on time data which are free from mistakes. This ERP system can run well under the active and proactive key users to implement it properly. To achieve this, the top management needs to build a company culture that can engage all middle managers or the heads of each department, or often called as the principal users, to be involved in the ERP practice. The role of the middle managers must be utilized fully by the top managers to get the benefit of the SCM performance through SCM practices and ERP system. Effect of SCM practice positive to the SCM performance [6]. Another research by Al-Shboul et al., [11] also confirms that the SC practice brings influences on the SC performance in the manufacturing companies.

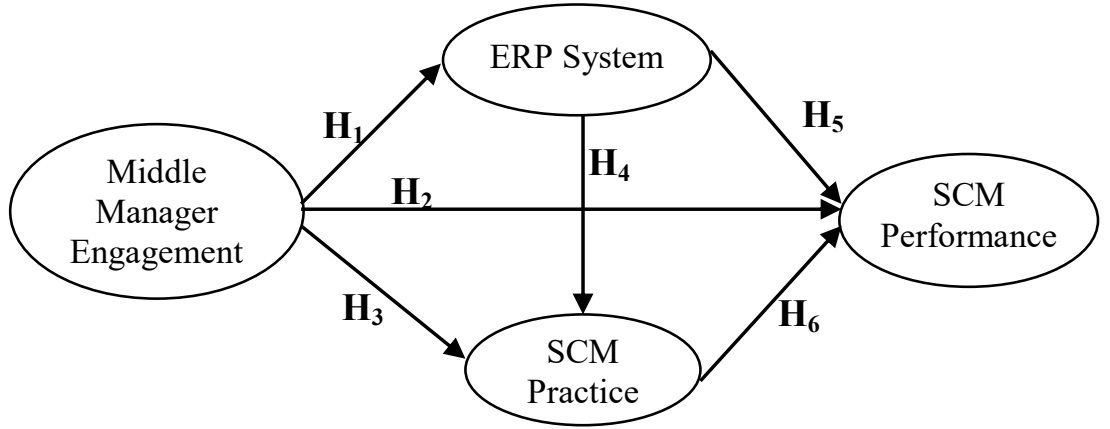

Fig. 1: The Conceptual Research Framework of ERP System, Supply Chain Practice and Performance

\section{Research Method}

The quantitative method is used to conduct this research, especially in East Java manufacturing, Indonesia. The chosen manufacturing companies as the analysis unit are those that have implemented the 
ERP software as the data integration among departments and those that have utilized the supply chain management so that there are collaborations with the suppliers and the customers. The data collection is done by distributing questionnaires to 60 manufacturing companies. The questionnaire is constructed using the Likert scale. Out of 81 returned questionnaires, 17 questionnaires are responded by the top managers and the first line supervisor, and there are four questionnaires that are not completed, making all of them invalid questionnaires. This research follows the procedures that are implemented by Al-Shboul et al. [11] for the prediction of validity and reliability. The validity model test with the outer loading value higher than 0.500 and the reliability test measured higher than 0.7 .

Outer loading for indicators variable middle manager engagement is their contribution to the department goals 0.885; actively in the communication with other departments 0.925 ; develop the job 0.669 and the opportunity to join training 0.897 . The indicators ERP system are: the smooth integration department functions 0.806; the accurate data integration 0.844; the complete data integrity 0.743 ; the adequate ERP data reliability 0.785 and the objective of the data integration is comprehensible 0.924 . The indicators SCM practice outer loading are supplier collaboration 0.717; information sharing 0.815; lean production 0.883 ; internal integration 0.926 and quality management 0.885 . Supply chain performance is the integrated information 0.772 ; perfect order fulfillment 0.855 ; flexibility 0.816 , responsiveness 0.802 and cost reduction 0.875 . Based on the results it can be said that all items have fulfilled the required reliability test, so it can be proceeded to conduct hypothesis analysis. Reliability for variable's middle manager engagement 0.868 : ERP system 0.883 ; SCM practice 0.884 and SCM performance 0.902

\section{Research Analysis}

The hypotheses of this research are to investigate the direct and indirect impacts of the middle manager engagement to the SCM performance, and statistical summaries can be observed in Table 1.

Table 1: Direct Effect of Middle Manager, ERP System and SCM Practice to SCM Performance

\begin{tabular}{|c|c|c|c|c|}
\hline Direct Effect & $\begin{array}{c}\text { Original } \\
\text { Sample }(\mathrm{O})\end{array}$ & $\begin{array}{c}\text { Standard } \\
\text { Deviation } \\
\text { (STDEV) }\end{array}$ & $\begin{array}{l}\text { T Statistics } \\
(|\mathrm{O} / \mathrm{STDEV}|)\end{array}$ & P Values \\
\hline ERP System -> SCM Performance & 0,251 & 0,125 & 2,014 & 0,044 \\
\hline ERP System -> SCM Practice & 0,259 & 0,073 & 3,523 & 0,000 \\
\hline Middle Manager Engagement -> ERP System & 0,386 & 0,118 & 3,282 & 0,001 \\
\hline Middle Manager Engagement -> SCM Performance & 0,282 & 0,120 & 2,362 & 0,018 \\
\hline Middle Manager Engagement -> SCM Practice & 0,598 & 0,091 & 6,588 & 0,000 \\
\hline SCM Practice -> SCM Performance & 0,350 & 0,110 & 3,192 & 0,001 \\
\hline
\end{tabular}

Table 1. shows that the direct effect of the middle manager engagement to the ERP system has the value of the t-statistic of 2.014 and the p-value of .044. As the t-statistic is higher than 1.96, the first hypothesis is accepted. It means that the effect of middle manager engagement to the ERP system. The direct involvement in communication among departments brings a clear and objective condition by integrating data from various departments in the company. Besides, the direct effect of the proper middle manager engagement to the enhanced SCM performance is reflected by the t-statistic of 2.362 and p-value of 0.018 . As the $t$-statistic is higher than 1.96, the second hypothesis is accepted. It means that the middle manager engagement positive impacts to the SCM performance. With their competencies and involvement, the middle managers can reduce the production cost, which is one of the SCM performance indicators for the company. Then, the direct effect of the middle management engagement to the supply chain practices is shown with the t-statistic value of 6.588 and the p-value of 0.000 . Since the t-statistic value is higher than 1.96, the third hypothesis is accepted. It means that the active middle manager involvement and good communication can bring good data integration between one department and others.

The fourth hypothesis is that the ERP system improvement impacts on the SCM practice in manufacturing companies in East Java, with the value t-statistic of 3.523 and the p-value of 0.000 . Since the t-statistic value is higher than 1.96, the fourth hypothesis is accepted. The ERP system positive impacts to the SCM practice in manufacturing companies. The good and accurate data integration to improve internal integration positively and significantly among departments. The ERP system can unite the departments within the companies through good data integration. The fifth hypothesis states that the ERP system affects 
SCM performance, and the statistical results show the value of the t-statistic of 2.014. As the t-statistic value is higher than 1.96, the fifth hypothesis is accepted. It means the ERP system affects the SCM performance in the manufacturing companies in East Java. The ERP system which integrates good and accurate data can reduce the operational costs of the company. The sixth hypothesis states that the implementation of SCM practice brings impacts to the SCM performance with the t-statistic value of 3.192 and the p-value of 0.001 . Because the t-statistic value is higher than 1.96, the sixth hypothesis is accepted. This means that the SCM practice affects to the SCM performance. The SCM practices within the company through good integration, quality management, and well-planned supply chain implementations can increase the performance of SCM, especially in the cost reduction and the perfect order fulfillment to all requests from customers in the manufacturing companies in East Java.

\section{Conclusion}

This research conducts six hypotheses test, and all hypotheses are accepted. The result of this research concludes that the middle manager engagement brings some impacts to ERP improvement through some direct and active involvements in communicating with other various departments. The middle manager engagement can bring some significant impacts to the implementation of the SCM in the companies by running the internal integration and quality management smoothly. The proper middle manager engagement brings also impacts to the improvement of the SCM performance by reducing the operational costs through efficiency and effectiveness. The enhanced ERP system also affects the SCM practice in the company as it coordinates the precise and accurate data integration and it enforces the smooth connectivity among departments. By building a good and stable system in the company, the ERP system can bring a significant impact on SCM performance. The implementation of SCM practices affects SCM performance, especially through improved quality management, internal integration among departments, and lean production systems. The operations of many manufacturing companies are managed and organized by middle managers. The middle manager engagement conducts some customizations to the ERP system and implements the best SCM practices sustainably so that the ERP system can improve the SCM performance.

\section{References}

[1] G.C. Stevens, and M. Johnson. Grating the Supply Chain ... 25 Years on. International Journal of Physical Distribution \& Logistics Management, 2016, 46 (1): 19-42.

[2] A.V. Gandhi, A. Shaikh, and P.A. Sheorey. Impact of Supply Chain Management Practices on Firm Performance: Empirical Evidence from a Developing Country. Int. J. of Retail \& Distribution Manag., 2017, 45 (4): 366-384.

[3] V.P.K. Sundram, A.R. Ibrahim, and Govindaraju. Supply Chain Management Practice in the Electronic Industry in Malaysia: Consequences for Supply Chain Performance. Benchmarking: An Int. J., 2011, 18 (6): 834-855.

[4] B. Ageron, O. Lavastre, and A. Spalanzani. Innovative Supply Chain Practice: The State of French Companies. Supply Chain Management: An Int. J., 2013, 18 (3): 265-276.

[5] W. Suprapto, Z.J.H.Tarigan, and S.R. Basana. The Influence of ERP System to the Company Performance Seen Through Innovation Process, Information Quality, and Information Sharing as the Intervening Variables. Proceedings ICEMT', 2017, 87-91.

[6] R. Chavez, B. Fynes, C. Gimenez, and F. Wiengarten. Assessing the Effect of Industry Clockspeed on the Supply Chain Management Practice-Performance Relationship. Supply Chain Manag.: An Int. J., 2012, 17 (3): 235-248.

[7] O.M. Ajayi, K. Odusanya, and S. Morton. Stimulating Employee Ambidexterity and Employee Engagement in SMEs, Management Decision, 2017, 55 (4): 662-680.

[8] L.S. Choo, N. Mat, and M. Al-Omari. Organizational Practices and Employee Engagement: a Case of Malaysia Electronics Manufacturing Firms, Business Strategy Series, 2013, 14 (1): 3-10.

[9] N. Khodakarami, K. Dirani, and F. Rezaei. Employee Engagement: Finding a Generally Accepted Measurement Scale. Industrial and Commercial Training, 2018, 50 (6): 305-311.

[10] S.W. Kim. Effects of Supply Chain Management Practices, Integration and Competition Capability on Performance. Supply Chain Manag.: An Int. J., 2006, 11 (3): 241-248.

[11] M.A.R. Al-Shboul, K.D. Barber, J.A.G-Reyes, V. Kumar, and M.R. Abdi. The Effect of Supply Chain Management Practices on Supply Chain and Manufacturing Firms Performance. Journal of Manufacturing Technology Management, 2017, 28 (5), 577-609. 